\title{
An Overview of Electronic Waste Management, Practices and Impending Challenges
}

\author{
Munam Ali Shah, PhD \\ COMSATS Institute of Information Technology \\ Islamabad
}

\begin{abstract}
Information and telecommunication technology (ICT) has penetrated deep into the human lives and is affecting human life style in different aspects. The rapid growth in ICT has embarked improvement in computing devices simultaneously decreasing product life and resulting in e-waste. This study examines various issues and challenges being faced by different countries in e-waste management. We will analyse what the legislations for e-waste management are and how they should be implemented in order to eliminate this issue.
\end{abstract}

\section{General Terms}

Electronic Waste (E-Waste), Recycling, Environmental Problems, Legislation, E-Waste management,

\section{Keywords}

Life Cycle Assessment (LCA), Material Flow Analysis (MFA), Multi-Criteria Analysis (MCA), Extended Producer Responsibility (EPR)

\section{INTRODUCTION}

In the modern era, everyone is an electronic consumer. People are using electronic appliances specifically computing devices very frequently. Rapid changes in information and communication technology, drastic reduction in prices of electrical appliances, and advancements in media and electronic world are playing an important role in increase in electronic gadgets. People keep on buying new computer systems and mobile phones almost every two months and dumping the old ones. Only a few people know what happens to that dumped electronic stuff[1].

\subsection{E-Waste}

Electronic Waste(E-waste), as the name depicts, comprises of electronic equipment such as computers, cell phones and other electrical devices which are destined for recycling or disposal[2]. Term WEEE is mostly used by EU for description of e-waste[3]. Due to greater use of electronic devices and their short life huge amounts of E-waste are piling up day by day. Every year almost 20-50 million tons of e-waste are being yielded throughout the world.[4] The amount of electronic dump generated globally has been estimated to reach about 72 billion tons annually by 2017. [5]

E-waste is physically and chemically different from all other types of wastes as it contains various kinds of materials that are hazardous but along with that it also contains a number of valuables[6]. These valuables can be material things or any kind of information. This information can be a source of potential security threat as it can provide some useful information to the opponents.

The gross objective while designing national e-waste management legislation should be the conception of

\author{
Rakhshanda Batool \\ COMSATS Institute of Information Technology \\ Islamabad
}

ecological recycling society that must precede the rules and regulations being specified. Different kind of strategies can be followed to manage e-waste. These strategies may include LCA, MFA, MCA, and EPR. Important factors involved in EWaste recycling are recycling, disposal, sorting and recovery and collection, as shown in Figure 1[6].

E-waste problem appeared initially in developed countries and now extend widely to other countries. Major portion of the ewaste collected for recycling from developed countries is being sent for processing or disposal to the developing world. China, India, Pakistan and Nigeria are the leading destinations for e-waste disposal[7].

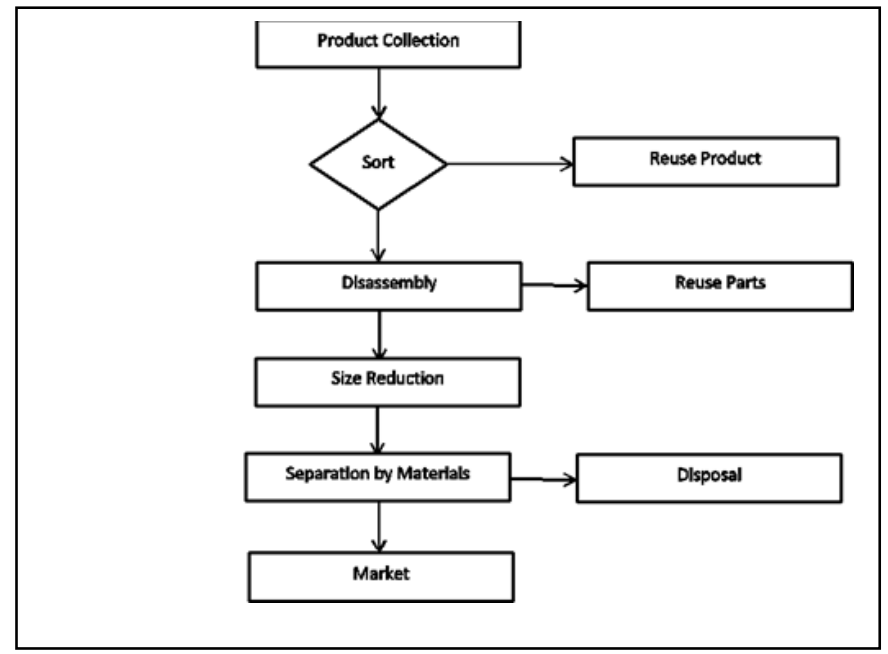

Fig. 1. Flow diagram for recycling of an electronic component

By analyzing e-waste disposal current situation and its treatment, this paper reviews the health and environmental aspects of E-Waste and most appropriate solutions to handle this situation. This paper will also discuss various legislations and methods that can be used for E-waste proper management.

E-waste is a prevailing issue in the whole world. This issue showed up at first in developed nations and now stretches out broadly to different nations all over the world. Its bulk is developing quickly on the grounds that consumer innovation is quickly altering and the development of innovative ideas in technology is quick and appliances are quickly getting out of date in quality. This is resulting in need for creating enormous measures for e-waste.

E-waste consists of a wide range of tools comprising of a mixture of poisonous constituents polluting surroundings and undermining social wellbeing. Numerous contextual analysis 
of e-waste recyclers affirmed that lethal compounds proceed to pollute the encompassing situation. It resulted in extensive gathering of dangerous constituents into the biological community that antagonistically affected social wellbeing. Research Centre imitation readings from transfer destinations rate the arrival of poisonous substances from e-wastes with the focus differing fundamentally in the middle of field and lab based studies.

Electronic waste is a nonexclusive word grasping diverse types of electric or electronic hardware that are of no use for their proprietors[8]. Electronic hardware (WEEE), or end-oflife (EOL) gadgets, signifies automated and electrical gear, that includes all parts and sub-get-togethers esteemed out of date or undesirable by a client[9]. E-waste consists of dangerous materials as well as precious metals[10]. This is the major reason they are being collected and re-used. Table I shows various options for product life cycle and product end of life[11].

E-Waste is artificially and substantially particular from diverse manifestations of metropolitan waste. It comprises of important and hazardous resources that accommodate unusual taking care of and reprocessing strategies to dodge ecological sullying and negative concerns for social welfare[12]. With the help of reusing, some of the reusable parts and materials can be recovered. Developed countries do not use e-waste due to less offices, high work expenses, and extreme natural regulations. Relatively, it is landfilled, or traded from rich nations to poor nations, where it is reprocessed employing simple approaches and slight admiration for specialist wellbeing of ecological security[2].

\section{E-WASTE MANAGEMENT PROCEDURES}

\subsection{Recycling}

Recycling or Reusing is an item recuperation choice that includes systems for making new materials from squanders. The focal points of reused materials are that they for the most part have a lower carbon foot shaped impression than crude materials delivered into completed products through a carbon serious procedure[13]. Inconceivable amounts of e-waste are presently sent for reuse in under developed nations utilizing labor-intensive techniques as a part of lawns of private properties, bringing about noteworthy tainting of soil, water and air in these nations. Guoyu and Taizhou in China, Gauteng in South Africa, New Delhi in India, Accra in Ghana and Karachi in Pakistan are the substantial e-waste reusing locales and broad contamination is radiated here from the ewaste reusing procedures[14].

\subsection{Landfills}

Independent of the contemporary worldwide transfer in the direction of zero squanders, quantity of landfills expanded throughout the world. While the proprietors of cutting edge landfills contend that as of late developed landfills are equipped for securely separating from the environment the poisons found in hardware, the vicinity of a huge number of old landfills with no boundary, enclosing a combination of putrescible and e-squanders is important[14].

\subsection{Composition of E-Waste}

Electronic Waste consists of electronic apparatuses for excitement, apparatuses shaping piece of office, correspondence and data innovation and family unit machines E-waste comprises of above than 1000 unique constituents, a large number of which are lethal, for example, lead, mercury, arsenic, cadmium, selenium, hexavalent chromium, and fire retardants that make dioxins discharges when copied. Around $70 \%$ of the overwhelming metals (mercury and cadmium) in US landfills originate from electronic waste. Buyer hardware makes up $40 \%$ of the lead in landfills. These poisons can bring about mind harm, unfavorably susceptible responses and disease[8]. These materials are increasingly causing global issues causing a major effect on global warming[15]. Table I shows hazardous constituents of e-waste in detail[8].

Table 1:Electronic Products, Their Life Cycle Options And Hazardous Elements

\begin{tabular}{|c|c|c|c|}
\hline Products & $\begin{array}{l}\text { Hazardous } \\
\text { elements }\end{array}$ & $\begin{array}{l}\text { Product } \\
\text { Life } \\
\text { Cycle } \\
\text { Options }\end{array}$ & $\begin{array}{l}\text { Product } \\
\text { End of } \\
\text { Life } \\
\text { Options }\end{array}$ \\
\hline \multirow{6}{*}{$\begin{array}{l}\text { Computing } \\
\text { Machines , } \\
\text { CRTs, } \\
\text { batteries, } \\
\text { Cameras, } \\
\text { Televisions, } \\
\text { Automatic } \\
\text { dispensers, } \\
\text { Household } \\
\text { appliances, } \\
\text { Lighting } \\
\text { equipment, } \\
\text { Electric and } \\
\text { electronic } \\
\text { tools }\end{array}$} & \multirow{6}{*}{$\begin{array}{l}\text { Cadmium, } \\
\text { Lithium, } \\
\text { Bromine, } \\
\text { Lead, } \\
\text { chromium, } \\
\text { Zinc, Nickel, } \\
\text { Barium, } \\
\text { Beryllium, } \\
\text { Dioxins, } \\
\text { Flame } \\
\text { retardants, } \\
\text { Biphenyls , } \\
\text { Polyaromatic } \\
\text { hydrocarbons, } \\
\text { Arsenic, } \\
\text { Selenium }\end{array}$} & Selling & Recycling \\
\hline & & $\begin{array}{l}\text { Storing } \\
\text { at home }\end{array}$ & Land filling \\
\hline & & Use & Incineration \\
\hline & & Reuse & \\
\hline & & Giving & \\
\hline & & Export & \\
\hline
\end{tabular}

\subsection{Security issues}

E-waste is causing serious security concerns[16]. It is a potential security threat specifically for large organizations that must have to keep their data tightly secured. Electronic devices when changed or replaced are sent for recycling or dumping. That e-trash may contain storage devices. If the data has been deleted from those devices, it can be retrieved back and recovered by using different kinds of techniques. When organizations send their e-trash for recycling, they must make it sure where there data is going to be sent. Opponents can take that e-trash and can recover important secured information. This can cause a major problem and hence is a security threat[17].

\subsection{Case Studies of Various Countries}

Developed as well as under developed countries are facing a lot of problems in managing e-waste. Table II shows an overview of challenges faced by various countries[18].

\subsubsection{E-Waste situations in US}

In $2006,32.5 \%$ of produced metropolitan left-over has been reused by United States. Almost 15 million EOL vehicles were created there, reliably. Instantly, $95 \%$ of automobiles are led to present reusing workplaces for devastating towards the end of their organization lives[19]. E-waste could be the quickest developing part of the MSW stream mostly on the grounds that individuals are acquiring, redesigning and tossing electronic items more as often as possible as any other time in recent memory. This pattern is prone to proceed with given the current vivacious rate of mechanical advancement and ensuing diminishing life compasses of electronic items[9]. 
U.S Environmental Protection Agency (EPA), stated that between 2003 and 2005, around $80-85 \%$ of the e-waste arranged for end-of-life organization ended up in U.S. landfills. U.S sent out its E-waste to developing countries which is in contradiction of the Basel Convention Agreement. Notwithstanding the U.S. e-waste circumstance, numerous states in the U.S. have started endeavors to gather and to reuse the e-waste from private and business areas. Absence of a productive gathering, reuse framework is one of the issues for e-waste administration in the U.S. Social basic is an important point in the U.S. for business sector focused arrangements that permit rivalry.

Following three qualities should be fulfilled by a storediscount framework in the U.S.

- Gathers income to guarantee legitimate reusing

- Do gives a money related motivation to customers to turn in their hardware

- makes a business sector, where multinationals contend to compromise additional productive recycle and waste managing administrations[9].

\subsubsection{E-Waste situations in China}

China is being considered as a developed country with fast economic growth. It is the country where electronic appliances are produced at a very quick rate[20]. Since 2004, the State Development and Reform Commission (SDRC) assigned Qingdao Haier, Hangzhou Dadi, Beijing Huaxing, Tianjing Datong as national pilot ventures, expecting to create WEEE reusing framework and administration techniques. Notwithstanding, slight advancement has been made as of not long ago[21]. The Chinese government is aware of ecological issues aroused by electronic waste from a long time and had released a mixture of natural laws, regulations, norms, specialized directions, standards identified with electrical articles generation and e-waste administration. . According to a survey almost $70 \%$ of e-waste is being processed in China on annual basis[22]

A few broad ranged natural laws are pertinent to e-waste administration, for example, the General Environmental Law National People's Congress, NPC, has put forward tenets identified with "contamination aversion" and "contaminator compensations" standards, The Clean Production Promotion Law demands that brands of items and bundling resources included in the required reuse list must obey the obligation to reuse those items and bundling constituents toward the EOL, and The Solid Waste Pollution Control Law which on a fundamental level directs strong squanders ought to be diminished, appropriately reused and discarded in a naturally stable way, and foundations and people who produce strong squanders ought to take legitimate measures to forestall and diminish the contamination brought about by those squanders[23].

An examination of the recuperation chain uncovers the real motives overdue the flourishing condition of China's casual reusing part:

- Adequate provisions brought by unlawful importations and household single accumulations

- $\quad$ Truncated management expenses kept up by relating basic and polluted strategies
- Very indicated disassembling courses of action which augment the recuperation of useful esteem by well-organized partition of ecological segments

- Persistent downstream requests that ingest the lion's share of distinctive items from casual workspaces

The absence of value control of recycled gadgets likewise allows open trade section of inadequate or uncertified items from unlawful reassembling methodology[24].

\subsubsection{E-Waste situations in Switzerland}

Switzerland is a top of the line, full grown customer business sector for electronic and electrical items. It has reliably top positioned, spending US\$ 3618 every capita in 2001, according to capita ICT. Here e-waste was pretty nearly $2.6 \%$ of the aggregate city strong waste stream in 2003. It has been a forerunner in enacting e-waste administration. Legitimately, Swiss Federal Office for the Environment presented e-waste administration in 1998[25]

In the opposite supply network, the purpose of offer is the perfect purpose of take back. The Swiss ORDEE likewise had made it obligatory for traders to take back e-waste from end customers complimentary. Retail take back is practical due to a few advantages it gives. In Switzerland, there is almost no esquander that goes as civil strong waste and the measurable phase is generally shut; entire partners have a very much characterized and fair part to perform and it is a straightforward framework with short authoritative expenses.

\subsubsection{E-Waste situations in China}

It is accounted for that fast monetary development in most Asian nations is expanding the measures of WEEE created in these nations. gauge that around $4 \mathrm{~K}$ huge amounts of WEEE are tossed universally every hour, $80 \%$ of which are sent out to Asia, with China accepting $90 \%$ of this offer[26]. Some countries including Korea, Japan and China are trying to enforce e-waste legislations by following EPR policy[3]. In comparison number of electronic appliances used in these countries, arrangements for proper disposal and recycling are very low[27]. Developed countries are trying to implement proper infrastructure but still they need a proper focus and layout to follow. Due to lack of this planning these countries are facing serious health and environment issues. Asian countries collect e-waste majorly to collect different kinds of metals from used electronics. China and Vietnam have major concern in gold and copper recovery[28].

\section{APPROACHES TO ACCOMPLISH E- WASTE}

The worldwide e-waste generation is evaluated to increment because of the financial development and the accessible innovations since the expanded Gross domestic product prompts expanded buying of electronic merchandise and in the long run to expanded e-waste creation[19]. At present broad examination exists in e-waste administration to alleviate issues at national and worldwide stages. A few instruments have been created and connected to e-waste administration. Some of these strategies are discussed here.

\subsection{Life Cycle Assessment (LCA):}

It is an implementation accustomed to plan earth amicable electronic gadgets and to minimize e-waste issues. Since the 1990s extensive examination has been led on the LCA of electronic gadgets as far as eco-outline, item improvement and ecological effects. A naturally well-disposed outline is a superior option item and it might thus engage buyers. LCA is 
an effective instrument for recognizing potential natural effects to create eco-plan items[14]. It is a well-developed methodology which is being used by several organizations to monitor e-waste during all of its stages[30].

\subsection{Material Flow Analysis (MFA):}

It is an apparatus familiar to study course of material streaming into reusing locales, or transfer zones and loads of tools, in space and time. It connects foundations, paths, and the intermediary and last endpoints of the gadget. It is a choice bolster instrument for ecological and waste administration[14].

It is obvious from the study led by Streicher-Porte that coupling of MFA and financial assessment is a helpful instrument when constrained information is accessible and where there is quick monetary development. In this methodology materials or e-waste is quantified following a series of steps. Different indicators are used to assess the working of this technique. Materials are categorized according to type, location, inputs and outputs before and after recycling

procedure[31].

\subsection{Multi-Criteria Analysis (MCA):}

It is a managerial technique used for making an allowance for deliberate judgements and resolving difficult multi-standards complications that consist of qualitative/computable characteristics of the problem[14].

\subsection{Extended Producer Responsibility (EPR)}

It is a domain strategy methodology that credits obligation to producers in retrieval of items when utilization has been done, and is in view of contaminator-compensations standards[14].

\subsection{Health Implications}

Antagonistic wellbeing impacts on individuals from contact with unsafe squanders may include any organ framework, contingent upon the particular organic substance(s) reached, degree of presentation, attributes of the uncovered individual (age, sex, body weight, hereditary cosmetics, immunological status), the digestion system of the chemical(s) included,

\section{A-SURVEY ON E-WASTE SITUATIONS IN PAKISTAN}

Pakistan is an under developed country with a low economy rate. E-waste dumping is a critical issue which is resulting in serious health problems. It has been noticed that the developing states are continuously sending their waste materials to under developed countries especially Pakistan. Major reason for the import of e-waste in Pakistan is that there are no proper rules and regulations for e-trash imports.

In this part of paper we conduct a survey questionnaire. The purpose is to ask the respondents about the required knowledge of e-waste and then to analyze the reason for its prevailing issues and to propose appropriate measures to reduce the hazards of e-waste. The respondents are categorized into students, IT professionals and non IT/other persons. Figure 2 below shows the relation between age group and number of respondents. climate conditions, and the vicinity or nonattendance of puzzling variables, for example, different illnesses[32]. Through immediate inward breath, dermal introduction and oral admission of sustenance and water, specialists and neighborhood inhabitants may be influenced by the lethal toxins. There is logical confirmation that dangerous affluences can be put away in specific issues through bioaccumulation and biomagnifying, prompting the development of the body weight of these mixes[21]. The heavy metals such as cadmium, chromium and lead that are taken out from e-waste cause more hazardous effects in children as compared to adults[33]. They result in serious health problems causing cancers, lungs diseases and death of infants [34].

\subsection{Challenges in implementations}

Both in nations of source and destination, there are a predetermined number of individuals included in location, regardless of the large number of government organizations managing it. Natural inspectorates assume a vital part and normally have the most specialized aptitude about waste matters. Ecological inspectorates are additionally those with most learning about waste gathering, treatment or transfer offices. This implies that they can address organizations on their permit in instances of regulatory infringement and may have the capacity to follow illicit waste exchange back to its source. There is however a genuine absence of limit for authoritative follow-up of illicit waste transports, since inspectorates have restricted staff. Cops concentrate on natural issues and lead criminal examinations concerning waste extortion however, similarly, they are restricted in staff and assets.

One approach to run over any unlawful transport of e-waste is through the control of shipments in harbors. To a certain degree, this is similar to searching for a needle in a sheaf. Traditions assume a vital part in this through their danger examination framework for filtering and physically reviewing shipments. Then again, ecological issues are not a need for traditions, bringing about restricted backing from the progression. Besides, the issue obliges specialized aptitude that is not given in preparing. Regardless of their insight and experience being pivotal for the control of waste transports, implementation offices are obliged by their constrained[5].

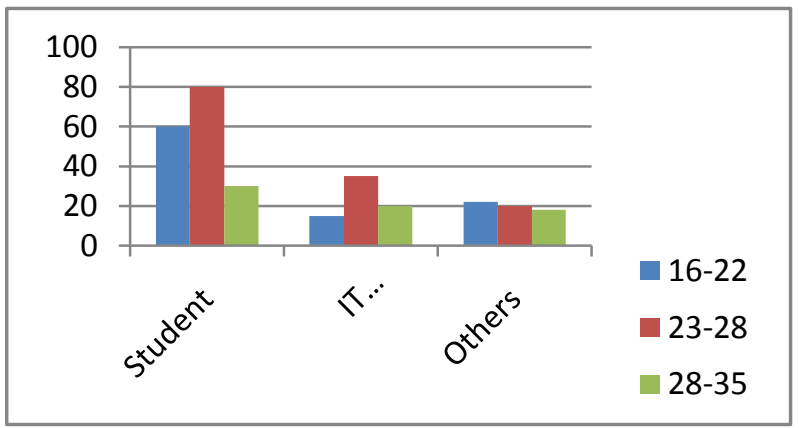

Fig. 2. Relationship between age factor and categories of respondents

In this survey, we also considered gender. Figure 3 depicts division based on gender group. 


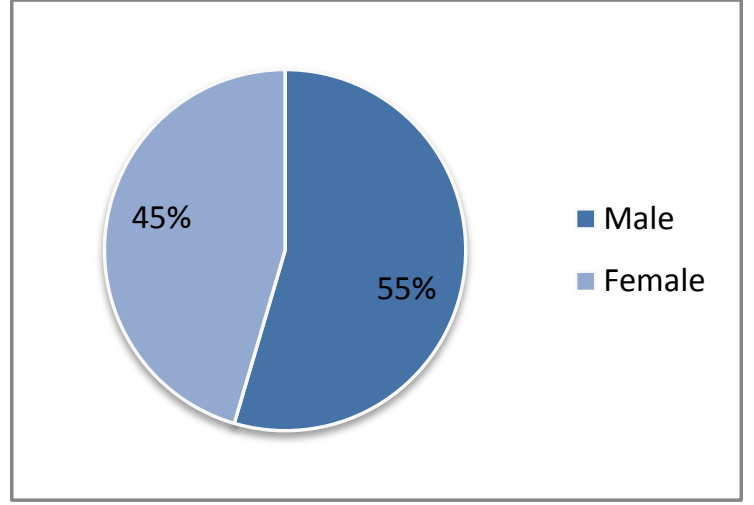

Fig. 3. Relationship between gender group

The first question of our survey was about the awareness of ewaste. The results obtained are plotted in Figure 4. According to this almost $70 \%-80 \%$ of population in Pakistan is unaware about e-waste. It has also been observed that people of age group 23-28 were more aware about it as compared to the others.

We then asked the respondents whether they are aware of the results of e-waste on our lives. The results were very interesting and have been plotted in Figure 5.

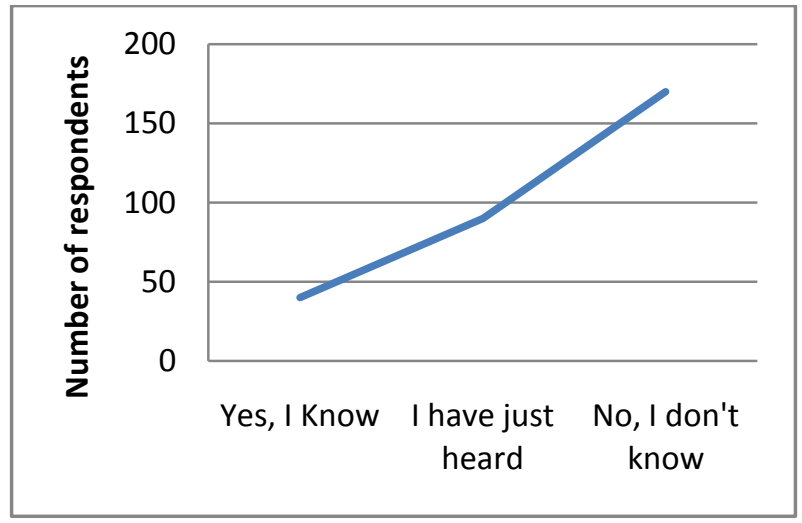

Fig. 4. Awareness about e-waste

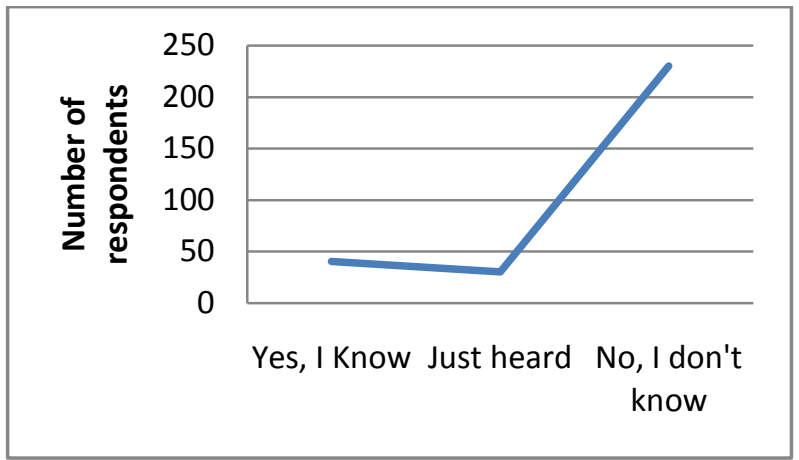

Fig. 5. Awareness about effects of e-waste

Most of the people don't even know that e-waste has any kind of effects on our lives. Even educated community is not so much well aware about its hazardous effects. They are just concerned with getting the materials at a very low rate. They don't even know that these materials contain toxic substances such as lead, chromium, mercury and cadmium that will damage their health and will pollute the environment.
There is a big industry for recycling of materials in Karachi. Many children are working in that industry and are unaware how badly they are being affected by that raw material. Industries have their major concern in getting valuable items from the e-waste and don't bother about children's health and pollution. These companies get valuable materials from the ewaste for selling and dispose other materials in an unsafe manner.

Pakistan is in need of a special policy to handle this critical situation and that policy must be implemented on urgent basis. Pakistan Environmental Act 1997 (PEA 1997) has been implemented by Pakistan Environment Protection Agency. It is being focusing to reduce pollution related issues in Pakistan but still it don't have any policy implementation regarding safe disposal of e-waste. Government needs to pay special attention towards awareness of e-waste disposal, so that common people can come to know its hazardous effects. It also needs to implement strict rules and regulations for import of e-waste in Pakistan, as China and India has started implementation.

Pakistan has signed the Basel Convention on the Control of Trans-boundary Movements of Hazardous Wastes and their disposal. But government has done not any significant work in checking and regulation of policy implementation.

\section{CONCLUSION}

In this paper, we studied different aspects of e-waste, its hazardous effects on environment and human health. We conducted a survey and asked various questions from people of different age groups and different fields. It revealed some interesting facts. People are very anxious to get new technology and electronic gadgets at a very low cost, and for this they preferably buy already used materials. They have no concern they how badly they are being affected by the ewaste. They have no knowledge how to dump that e-waste and they are not being properly guided in this matter. It is anticipated that if these e-waste situations will remain consistent, they will result in a lot of problems. In future we aim to investigate various other problems related to e-waste in Pakistan and will propose an authentic solution to reduce this problem. We would be concentrating to aware major environmental organizations for these possible threats and to involve those organizations to impose proper rules and regulations to secure Pakistan from vulnerabilities of e-waste.

\section{REFERENCES}

[1] P. Pak, "Haste Makes E-Waste: A Comparative Analysis of How the United State Should Approach the Growing E-Waste Threat," Cardozo J. Int. Comp. Law, vol. 16, 2008.

[2] B. H. Robinson, "Science of the Total Environment Ewaste: An assessment of global production and environmental impacts," Sci. Total Environ., vol. 408, no. 2, pp. 183-191, 2009.

[3] A. Terazono, S. Murakami, N. Abe, B. Inanc, Y. Moriguchi, M. Kojima, A. Yoshida, J. Li, J. Yang, M. H. Wong, A. Jain, G. L. P. C. Lin, T. Mungcharoen, and E. Williams, "Current status and research on E-waste issues in Asia," Journal of Material Cycles and waste Management, Vol 8, no. 1, pp 1-12, March 2006.

[4] S. Schwarzer, A. De Bono, G. Giuliani, S.Kluser, and P.Peduzzi, "E-waste, the hidden side of IT equipment's manufacturing and use," Environment Alert Bulletin, Jan.2005. 
[5] L. Bisschop, "How e-Waste Challenges Environmental Governance," Int. J. Crime, Justice Soc. Democr., vol. 3, no. 2, pp. 81-85, Aug. 2014.

[6] F. Wang, J. Huisman, C. E. M. Meskers, M. Schluep, A. Stevels, and C. Hagelüken, "The Best-of-2-Worlds philosophy: developing local dismantling and global infrastructure network for sustainable e-waste treatment in emerging economies.," Waste Manag., vol. 32, no. 11, pp. 2134-46, Nov. 2012.

[7] S. Sthiannopkao and M. H. Wong, "Handling e-waste in developed and developing countries: initiatives, practices, and consequences.," Sci. Total Environ., vol. 463-464, pp. 1147-53, Oct. 2013.

[8] R. Widmer, H. Oswald-Krapf, D. Sinha-Khetriwal, M. Schnellmann, and H. Böni, "Global perspectives on ewaste," Environ. Impact Assess. Rev., vol. 25, no. 5, pp. 436-458, Jul. 2005.

[9] R. Kahhat, J. Kim, M. Xu, B. Allenby, E. Williams, and P. Zhang, "Exploring e-waste management systems in the United States," Resour. Conserv. Recycl., vol. 52, no. 7, pp. 955-964, May 2008.

[10] S. B. Wath, A. N. Vaidya, P. S. Dutt, and T. Chakrabarti, "A roadmap for development of sustainable E-waste management system in India.," Sci. Total Environ., vol. 409, no. 1, pp. 19-32, Dec. 2010.

[11] P. Tanskanen, "Management and recycling of electronic waste," Acta Mater., vol. 61, no. 3, pp. 1001-1011, Feb. 2013.

[12] K. A. and D. A. G. Gaidajis*, "E-waste: Environmental Problems and Current Management," J. Eng. Sci. Technol. Rev., 2010.

[13] S. Wibowo, H. Deng, and X. Zhang, "Evaluating the Performance of E-Waste Recycling Programs using Fuzzy Multiattribute Group Decision Making Model," 2014 IEEE 9th Conf. Ind. Electron. Appl., 2014.

[14] P. Kiddee, R. Naidu, and M. H. Wong, "Electronic waste management approaches: an overview.," Waste Manag., vol. 33, no. 5, pp. 1237-50, May 2013.

[15] S. Saxena, "Green Computing: Need of the Hour," Int. J. Curr. Eng. Technol., vol. Vol.5, No., no. 07 Feb 2015, 2015.

[16] T.Butler, M.Daly, "No TitleEnvironmental responsibilty and green IT: An institutional perspective," Eur. Conf. Inf. Syst., vol. 10, 2008.

[17] S. Murugesan and G. R. Gangadharan, "Harnessing Green It: Principles and Practices," Harnessing Green It Princ. Pract., no. February, 2012.

[18] M. B. Nur, S. Supian and M.Yusof, "Current Waste Generation Of E-Waste And Challenges In Developing Countries: An Overview," Malaysian J. Civ. Eng., vol. 27, no. 1, pp. 110-120, 2015.

[19] H.-Y. Kang and J. M. Schoenung, "Electronic waste recycling: A review of U.S. infrastructure and technology options," Resour. Conserv. Recycl., vol. 45, no. 4, pp. 368-400, Dec. 2005.
[20] E.Y. Zeng, K. Zhang, and J. L. Schnoor, "E-Waste Recycling: Where Does It Go from Here?," American Chemical Society, 2012.

[21] L. Wei and Y. Liu, "Present Status of e-waste Disposal and Recycling in China," Procedia Environ. Sci., vol. 16, pp. 506-514, Jan. 2012.

[22] X. Zheng, F. Xu, K. Chen, Y. Zeng, X. Luo, S. Chen, B. Mai, and A. Covaci, "Flame retardants and organochlorines in indoor dust from several e-waste recycling sites in South China: composition variations and implications for human exposure.," Environ. Int., vol. 78, pp. 1-7, May 2015.

[23] J. Yu, E. Williams, M. Ju, and C. Shao, "Managing ewaste in China: Policies, pilot projects and alternative approaches," Resour. Conserv. Recycl., vol. 54, no. 11, pp. 991-999, Sep. 2010.

[24] X. Chi, M. Streicher-Porte, M. Y. L. Wang, and M. A. Reuter, "Informal electronic waste recycling: a sector review with special focus on China.," Waste Manag., vol. 31, no. 4, pp. 731-42, Apr. 2011

[25] D. S. Khetriwal, P. Kraeuchi, and R. Widmer, "Producer responsibility for e-waste management: key issues for consideration - learning from the Swiss experience.," $J$ Environ. Manage., vol. 90, no. 1, pp. 153-65, Jan. 2009.

[26] F. O. Ongondo, I. D. Williams, and T. J. Cherrett, "How are WEEE doing? A global review of the management of electrical and electronic wastes.," Waste Manag., vol. 31, no. 4, pp. 714-30, Apr. 2011.

[27] Jennifer Joines, "Journal of Social Justice, Vol. 2, 2012 (C) 2012),” J. Soc. Justice, vol. 2, 2012.

[28] F. C. B. Atsushi Terazono*1, Masahiro Oguchi\ Aya Yoshidal, Hidetaka Takigamil, Tetsuro Agusi and T. F. Jr. 3, "E-waste recycling in Asia: process classification, environmental effect and knowledge sharing."

[29] B. H. Robinson, "E-waste: an assessment of global production and environmental impacts.," Sci. Total Environ., vol. 408, no. 2, pp. 183-91, Dec. 2009.

[30] J. Hong, W. Shi, Y. Wang, W. Chen, and X. Li, "Life cycle assessment of electronic waste treatment.," Waste Manag., vol. 38, pp. 357-65, Apr. 2015.

[31] J. Mangold, K. Cristobal, C. Mars, and D. Dornfeld, "Assessment Framework and Material Flow Analysis of Material Recovery Facilities Within the U.S. to Track Consumer Electronics by Product Category," Procedia CIRP, vol. 29, pp. 556-561, 2015.

[32] I. C. Nnorom and O. Osibanjo, "Electronic waste (ewaste): material flows and management practices in Nigeria.,"Waste Manag., vol. 28, no. 8, pp. 1472-9, Jan. 2008.

[33] D. N. Perkins, M.-N. Brune Drisse, T. Nxele, and P. D. Sly, "E-Waste: A Global Hazard," Ann. Glob. Heal., vol. 80, no. 4, pp. 286-295, Jul. 2014.

[34] Q. Song and J. Li, "A review on human health consequences of metals exposure to e-waste in China," Environ. Pollut., vol. 196, pp. 450-461, Jan. 2015. 